\title{
Congenital cytomegaloviral infection as a risk factor for preterm birth
}

\author{
Kristin I. Orr, MD ${ }^{1}$ \\ Keywords: Cytomegalovirus, preterm birth
}

\section{Objective:}

Congenital cytomegalovirus (CMV) is the most common cause of congenitalacquired infection in the United States and preterm birth continues to be a world-wide public health problem. Given infection has been shown to play a role in preterm delivery; the objective of this study was to determine the prevalence of congenital CMV infection in a population of preterm infants and determine if it a risk factor for preterm birth.

${ }^{1}$ Department of Obstetrics and Gynecology, Carver College of Medicine, University of lowa Hospitals and Clinics, Iowa City, IA, 52242

\section{Methods:}

DNA was extracted from biologic samples (blood, saliva, buccal swabs) of preterm infants and multiplex PCR using primers and conditions optimized from previous studies was performed to detect CMV nucleic acids from human DNA. Chi-square and Fischer tests were used for statistical analysis.

\section{Results:}

Of the 1,200 premature infants tested, 37 tested positive for CMV (3.08\%). This finding is significantly higher than the $0.48 \%$ infection rate observed in term infants from lowa $(p=<0.001)$, significant $\left(P=1.7 \times 10^{-9}\right)$ difference by sample type with all of the CMV+ samples coming from buccal swabs. Comparing our rate among buccal swabs only to the published rate in buccal swabs from term infants we find there is a significantly higher rate in preterm infants $\left(P=4.1 \times 10^{-9}\right)$.

\section{Conclusion:}

This is largest study to date investigating the potential association between congenital CMV infection and preterm birth in a primarily Caucasian population. Given the higher rate of congenital CMV in our study, this demonstrates the need for a CMV screening program, and our results suggest that a main target population of such a program should be preterm infants. Buccal swabs may be the ideal sample type to use for screening purposes.

Please cite this paper as: Orr K. Congenital cytomegaloviral infection as a risk factor for preterm birth. Proc Obstet Gynecol. 2013;3(2):Article 10 [ 1 p.]. Available from: http://ir.uiowa.edu/pog/. Free full text article.

Corresponding author: Kristin Orr Department of Obstetrics and Gynecology, University of lowa, 200 Hawkins Drive, lowa City, IA 42242. kristin-orr@uiowa.edu

This is an Open Access article distributed under the terms of the Creative Commons Attribution 3.0 Unported License (http://creativecommons.org/licenses/by/3.0), which permits unrestricted use, distribution, and reproduction in any medium, provided the original work is properly cited. 